\title{
CONTRIBUTO À COMPREENSÃO HISTÓRICA DA CONSTITUIČÃO ECONÔMICA NO DIREITO COMPARADO $^{5}$
}

\section{LADEMIR GOMER DA ROCHA}

\section{RESUMO:}

O presente trabalho visa fixar as bases teórico-conceituais para a compreensão da constituição econômica, percorrendo uma vertente de estudo histórico-comparativa, calcada nas experiências constitucionais mais significativas na tradição jurídico-política do Ocidente. Parte-se para tanto da análise das experiências constitucionais do período clássico, ocasião em que as bases institucionais do livre-cambismo foram consagradas jurídicopositivamente. Em seguida, faz-se a análise das constituições do entreguerras, que, em contraste com o dualismo estrutural das constituições liberais, explicitaram, ao lado das tradicionais dimensões dogmática e orgânico-política, a organização jurídicopositiva das relações socioeconômicas. Finalmente, empreendese a análise de algumas das constituições européias do segundo pós-guerra, privilegiando o enfoque de seus preceitos de conteúdo econômico, bem como o desenvolvimento de seu significado jurídico-dogmático pela atuação de seus tribunais, notadamente os encarregados da jurisdição constitucional.

\footnotetext{
${ }^{5} \mathrm{~A}$ banca foi composta pelo Professor Doutor José Reinaldo Lima Lopes, Professor da Universidade de São Paulo e Doutor em Filosofia do Direito pela Universidade de São Paulo; pelo Professor Doutor Glênio José Wasserstein Hekman, Professor Adjunto da Universidade Federal do Rio Grande do Sul e Doutor em Direito pela Universidade de São Paulo, e pela Professora Doutora Martha Lucía Olivar Jimenez, Professora Adjunta da Universidade Federal do Rio Grande do Sul, Doutora em Direito pela Université Robert Schuman, Strasbourg, França. A referida defesa foi presidida pelo Professor Doutor Luís Afonso Heck, Professor da Universidade Federal do Rio Grande do Sul, Doutor em Direito Constitucional pela Universidade Federal de Minas Gerais, orientador do referido trabalho. Data da defesa: 09-02-2004
} 
O método de estudo, predominantemente analíticodescritivo dos principais documentos jurídico-normativos do direito constitucional comparado, busca portanto compreender, desde o constitucionalismo liberal, os fundamentos das diversas 'constituições econômicas', explícitas ou implícitas, e tomar evidentes as relações que se estabeleceram entre a constituição econômica formal, a constituição econômica material e a constituição econômica real em cada período e experiência histórica considerada relevante, bem como as articulações entre os fenômenos político-constitucionais e econômico-constitucionais, preocupando-se, portanto, não somente com os aspectos estáticoestruturais das normas e institutos constitucionais, mas também com os problemas funcional-dinâmicos decorrentes de sua concreta aplicação. 